Volume 5, Issue S1 (2020), pp. 42-48

Journal of School Administration Research and Development

ISSN: 2470-8496 Print/ ISSN: 2470-850X Online

ojed.org/jsard

\title{
Principal Candidates' Sense of Efficacy: Can They Lead During a Pandemic?
}

\author{
Kimberly W. Money \\ Linda C. Pacifici \\ Appalachian State University, USA
}

\begin{abstract}
Principal candidates' sense of self-efficacy is critical for their professional development. Analysis of a self-efficacy survey provided the authors with valuable insights into areas needed for program development. The purpose of this research-based essay is to report on data analysis results learned about the self-efficacy of 10 school leadership students during a summer principalship course. These results provide information about implications as well as specific suggestions for leadership program improvement related to crisis situations.
\end{abstract}

Keywords: crisis, efficacy, equity, leadership, pandemic, principal, teacher

Beginning on March 16, 2020, the Centers for Disease Control and Prevention (CDC) website published the daily number of new Covid-19 cases reported daily in the United States (US). Weekly averages of new reported cases from March 16 to July 11, 2020, reveal an upward trajectory except for two short spans in May and June. Attempting to stop the virus's spread in late February, continuing throughout March and into April, principals, superintendents, and governors closed K-12 schools across the nation (Education Week, 2020). The impact of school closures was immediately felt by parents, students, and teachers and also by school administrators beginning an unprecedented chapter in US K-12 schooling. The unexpected and immediate changes to in-person learning 
presented a critical need for principals to be able to make decisions quickly that will impact their entire school and community. What professionally developed characteristics support school principals' ability to make decisions during this crisis? Self-efficacy is one area that supports effective decision making in principals (Abernathy, 2018). Self-Efficacy is defined as the belief in one's ability to "coordinate and orchestrate skills and abilities in changing and challenging situations" (Maddux, 2012, para. 5). Self-efficacy has a positive impact on the overall practice of school leadership (Morgan, 2018). The purpose of this research-based essay is to gain insight into the self-efficacy of current principal candidates enrolled in a Masters of School Administration Program as they reflect on their ability to lead schools during a pandemic.

\section{MAIN ARGUMENT/LITERATURE}

The manner in which a principal responds to a crisis event is critical, especially during this pandemic. While principals work to establish a safe and supportive environment for all students, they are now faced with even greater challenges as they navigate a new health crisis in addition to the regular daily demands of the job. Smith and Riley (2012) explain that "leadership in times of crisis is about dealing with events, emotions and consequences in the immediate present in ways that minimize personal and organizational harm to the school and school community" (p. 1). Principal candidates in their future professional practice will encounter crises as part of their jobs. The unpredictability of crisis events makes principal preparation particularly challenging. Therefore, it is critical for principals to develop a strong sense of self-efficacy in order to make effective immediate and long-term decisions in any situation. Feeling confident about one's own ability to make effective decisions during times of crisis greatly affects the outcomes of those decisions, (Bandura, 1994). Examining principal candidates' self-perceptions of their capacity to lead during an unprecedented crisis provides valuable information for program faculty as well as for the students themselves.

\section{METHODOLOGY}

An online survey tool, Google Survey, was used to conduct research for this study. A mixed method approach was taken, as the questionnaire in the Google Survey was composed of both numerically rated questions along with short answer open-ended questions (Berends, 2006). The authors created a fifteenquestion survey that ten graduate students completed while taking a summer 
session course, The Principalship. In the survey, 11 questions are written in the Likert scale format (none, very little, somewhat, quite a bit, and significantly). The remaining four questions are in a short answer form. The survey was adapted from a principal questionnaire about general principal efficacy (TschannenMoran, n.d.). Each question aligned with one of three North Carolina state level principal leadership standards: strategic, instructional, and cultural leadership (NC Standards for School Executives, 2013).

Data analysis was conducted using an inductive process of constant comparison in the grounded theory method (Creswell \& Gutterman, 2019). Respondent frequency rates were calculated as percentages per Likert item for each question. Comparison of the percentages within each question as well as across questions enabled the authors to combine data results into categories. The categories with the highest level of percentages of high efficacy or low efficacy are reported.

The responses in the open-ended questions were read and reread as the authors looked for commonalities across responses within each question. Categories were identified from the collated responses. These categories became the major themes in data analysis.

\section{RESULTS}

Three themes emerged from data analysis reflecting students' sense of low efficacy in leading a school during a pandemic. The most significant finding falls within the cultural standard in which respondents indicated $(80 \%)$ that the biggest challenge for them is student access to technology resources. Eighty percent of the students feel they cannot raise student achievement. For example, while they feel strongly that they can facilitate teaching and learning, increasing achievement is not possible. These students believe they can only maintain current levels of achievement. Additionally, half of the respondents felt like they could manage, change, and shape operational policies for the school, and half felt they would not be able to manage and shape changing policies during a pandemic.

Two themes rated high for students' self-perception of high efficacy when leading during a pandemic. Eighty percent believe within the cultural standard that they can create a positive learning environment for students during a pandemic. The self-perceived sense of efficacy within the instructional standard is $70 \%$. These respondents believe they can successfully facilitate teaching and learning during a pandemic. Respondents felt that maintaining control of their professional schedule as well as being able to manage job demands, including job 
stress, was positively possible with an $80 \%$ response level. These concepts match the strategic leadership standard.

While respondents indicate they have a strong sense of self-efficacy during a pandemic for areas within each leadership category, other items indicate concerns about their ability to lead.

\section{DISCUSSION}

The purpose of this research was to investigate how graduate students enrolled in a principal leadership program believed they could lead during a pandemic such as the one that began in spring 2020. Insights learned from the inquiry were intended to inform principal preparation programs in order to support future principals who encounter a similar pandemic situation in the future. A strong sense of self-efficacy in a school principal when making crisis-based decisions ensures successful decision making.

A high level of survey respondents reported that they would not be able to raise student achievement in their schools during the pandemic. This survey finding could result from two interrelated factors. This may be due to the access and equity issues (i.e., resources, support at home, internet access, technology devices) that became apparent with the pandemic. Equity issues and access gaps during this pandemic were immediately highlighted when students needed to have equipment and resources in order to continue school. This insight could be the most critical revelation from this study.

A second factor involved the survey respondents' perceived inability to manage and change policies during a pandemic. Adding to the lack of technology resources for teachers and students' families, the pandemic created a survival atmosphere. Successfully navigating fast-moving and changing policies at the district and state level could create a survival outlook for these graduate students in their future leadership roles. Thus, in a typical crisis, principals make decisions quickly based upon one major known situation (e.g., lockdown due to a dangerous person on campus). The unknown factors of Covid-19 pandemic required principals to make numerous decisions immediately in order to keep all staff and students safe. The quick turnaround time in decisions made at the state level, which called for immediate action at the district level, left principals with little autonomy or time to implement supportive activities. Thus, during the early months of the pandemic, staff were not able to receive professional development and training needed to raise student achievement.

However, the results of the inquiry also indicate that these students believe they can successfully create a positive learning environment as well as 
facilitate teaching and learning for the students in their K-12 schools. The survey respondents believe they would be able to continue with their work as principals during a pandemic. Therefore, these future principals report the confidence that they can maintain minimum activities needed to secure a functional level of teaching and learning in their school.

\section{LESSONS LEARNED}

This research underscores the need for a new lens in revising school leadership programs. This lens could incorporate extended crises with in-depth teaching and learning for school leadership. Topics learned from this research would be included in, for example, case study analysis. In The Principalship course, an addition of case studies in a leadership skills section could be added to the course syllabus. Case study analysis could expand and deepen each student's ability to prepare proactively and manage immediately in a crisis situation. The case studies could require students to collectively problem solve pandemic or other crisis-related situations. Each case study could focus on one type of crisis, whether a health pandemic or armed person entering school grounds. These case study scenarios could include how to attain technology access for all families with students in the school. Additionally, these case studies could facilitate students' learning of how to navigate the rapid communication demands as well as finding needed resources during crisis situations.

Further, decision making during a crisis is a topic that needs to be included among course topics in course syllabi. This includes specific and explicit attention through readings and media-based resources along with connections to leadership theories focuses on deconstructing crisis decisionmaking.

Finally, a program review could reveal where, among courses in the program, an equity lens could be integrated in each course supporting crisis decision making. Additionally, principal efficacy for crisis decision making could be highlighted and added to an assessment matrix implemented for principal competencies across course assignments.

\section{FUTURE RESEARCH}

Future research is needed in the area of teaching principals how to lead at a level beyond a survival mode during a pandemic. If this specific inquiry was a longitudinal study, a follow-up survey could be administered to see if, with additional program study, the areas of low efficacy would shift to a high level of 
efficacy. Additionally, inquiries made with current principals on how they handled student learning during the pandemic would be valuable information for principal preparation programs. Another topic could be to document the implications for families who do not know how to use the equipment provided for them at home (e.g., how to log into the learning platform at home). More than access and equity issues, guardians need to learn how to use the learning management system to support student learning. This need is another critical issue that needs to be addressed through research. Principal self-efficacy development and pandemic-related crisis leadership learning is valuable information to gain in future research.

\section{CONCLUSIONS}

Overall, the findings of this study are positive in that these principal candidates indicate a high level of self-confidence and thus self-efficacy to perform their duties during a pandemic. The areas of concern can be addressed with either a crisis-leadership teaching strand among all courses in the program or through additional coursework. Important topics like decision making, technology resource attainment and equitable access, and moving beyond the status-quo with student achievement are possible to address in principal leadership preparation programs.

\section{REFERENCES}

Abernathy, D. (2018). Addressing skills, knowledge and self-efficacy in the online development of school leaders. Journal for the Advancement of Educational Research International, 12(1), 47-57.

Bandura, A. (1994). Self-efficacy. In V. S. Ramachandran (Ed.), Encyclopedia of human behavior (Vol. 4, pp. 71-81). New York: Academic Press. (Reprinted in H. Friedman [Ed.], Encyclopedia of mental health. San Diego: Academic Press, 1998). https://www.uky.edu/ eushe2/Bandura/BanEncy.html

Berends, M. (2006). Survey Methods in Educational Research. In J. L. Green, G. Camilli, \& P. B. Elmore (Eds.), Handbook of complementary methods in education research (p. 623-640). Lawrence Erlbaum Associates Publishers.

Creswell, J. \& Guetterman, T. (2019). Educational Research Planning, Conducting, and Evaluating Quantitative and Qualitative Research. Pearson. 
Centers for Disease Control and Prevention (CDC). Retrieved July 21, 2020, from https://www.cdc.gov/coronavirus/2019-ncov/cases-updates/casesin-us.html

Education Week. (2020, March 6). Map: Coronavirus and School Closures. Education Week. https://www.edweek.org/ew/section/multimedia/mapcoronavirus-and-school-closures.html

Maddux, J. (2012). Self-Efficacy: The Power of Believing You Can. In S. J. Lopez \& C. R. Snyder (Eds.), The Oxford Handbook of Positive Psychology (2nd ed., pp. 227-287). DOI: 10.1093/oxfordhb/9780195187243.013.0031

Morgan, T. (2018). Assistant Principals' Perceptions of the Principalship. International Journal of Educational Policy and Leadership, 13(10), 121.

North Carolina Department of Public Instruction (2013). North Carolina standards for school executives. Retrieved July 20, 2020, from https://files.nc.gov/dpi/north carolina standards for school executives 1.pdf

Smith, L., \& Riley, D. (2012). School leadership in times of crisis. School Leadership \& Management, 32(1), 57-71.

Tschannen-Moran,

M.

(n.d.).

Principal

Questionnaire. https://wmpeople.wm.edu/asset/index/mxtsch/pse

KIMBERLY W. MONEY, EdD, is an Assistant Professor in School Administration in the Leadership and Education Studies Department, Appalachian State University. Her major research interests lie in the area of teacher and principal preparation, principal efficacy, and data-driven instructional leadership. Email: moneykd@appstate.edu.

LINDA C. PACIFICI, PhD, is an Associate Professor in the Curriculum and Instruction Department, Reich College of Education, Appalachian State University. Her research interests are teacher preparation, curriculum program development, and instructional technology.Email: pacificilc@appstate.edu.

Manuscript submitted: August 14, 2020

Manuscript revised: September 10, 2020

Manuscript revised: September 18, 2020 Accepted for publication: September 22, 2020 